\title{
Dry matter accumulation and potato productivity with green manure
}

\author{
Acumulación de materia seca y productividad de papa con abono verde \\ Elsaid M.E. Mohamed ${ }^{1}$, Maristela Watthier ${ }^{1 *}, J_{\text {José C. Zanuncio }}^{2}$, Ricardo H.S. Santos ${ }^{3}$
}

\begin{abstract}
Growth patterns and distribution of dry matter in different parts of potato plants (Solanum tuberosum, Solanaceae) with green manure can be positively influenced by the use of green manure. The aim was to evaluate the dry matter accumulation and productivity of potato with varying quantities of sunn hemp, Crotalaria juncea (Fabaceae) as a nitrogen source. The experiment used three different amounts of sunn hemp, equivalent to 100, 200 and $400 \mathrm{Kg} \mathrm{ha}^{-1}$ nitrogen $(\mathrm{N})$, the recommended mineral $\mathrm{N}$ dose $\left(250 \mathrm{Kg} \mathrm{ha}^{-1}\right)$, and a treatment with zero N. Sampling was carried out at 35, 50, 65 and 80 days after planting, representing the subplots. The treatments were arranged in a randomized block design with split plot, the plot were enlarged fertilization and the small plot sampling dates. Four replications were used. Dry matter accumulation in the shoots of potato was greater with sunn hemp than with mineral nitrogen. The accumulation of dry matter in tubers and in the whole plant increased over time at higher rates of sunn hemp than with mineral fertilizer. Commercial and total potato productivity increased with sunn hemp quantity. Green manure at higher rates ( 400 and $200 \mathrm{Kg} \mathrm{ha}^{-1}$ ) increased the accumulation of dry matter in potato aboveground parts and in tubers. The commercial productivity of potato was $24 \%$ greater with green manure than with mineral fertilizers, indicating the potential of sunn hemp to provide adequate quantities of nitrogen for the growth and development of this crop.
\end{abstract}

Key words: Crotalaria juncea, harvest index, nitrogen, Solanum tuberosum.

\section{RESUMEN}

Los patrones de crecimiento y la distribución de materia seca en las diferentes partes de la planta de papa Solanum tuberosum (Solanaceae) pueden ser influenciados positivamente por la utilización de abono verde. El objetivo del trabajo fue evaluar la acumulación de materia seca y el rendimiento de papa con diferentes dosis de Crotalaria juncea (Fabaceae) como fuente de nitrógeno. En el experimento se utilizó tres dosis de crotalaria, equivalente a 100, 200 y $400 \mathrm{~kg} \mathrm{ha}^{-1}$ de $\mathrm{N}$, la dosis mineral recomendada para el cultivo $\left(250 \mathrm{~kg} \mathrm{ha}^{-1}\right.$ de N) y un tratamiento sin fertilización. Se realizó muestreos a los 35, 50, 65 y 80 días después de la siembra, representado a las subparcelas. Se utilizó un diseño experimental en bloques al azar con arreglo en parcelas divididas, la parcela consideró dosis de fertilización y las subdivisiones las fechas de muestreo. Se consideró cuatro repeticiones por tratamiento. La acumulación de materia seca en la parte aérea fue mayor en plantas de papas manejadas con crotalaria en comparación con plantas fertilizadas con la dosis mineral. En los tubérculos y en la planta entera, la tasa de acumulación de materia seca aumentó por medio del tiempo y fue mayor con la crotalaria que con la dosis mineral. El rendimiento comercial y el rendimiento total de papa aumentaron en función de la cantidad de la crotalaria. Altas dosis (400 y $\left.200 \mathrm{~kg} \mathrm{ha}^{-1}\right)$ incrementaron la acumulación de materia seca en la parte aérea de la planta y en el tubérculo. El rendimiento comercial de la papa con crotalaria fue $24 \%$ mayor que con la dosis mineral, esto demuestra el potencial de este abono verde para suplir las cantidades adecuadas de nitrógeno requerido para el crecimiento y desarrollo de este cultivo.

Palabras clave: Crotalaria juncea, índice de cosecha, nitrógeno, Solanum tuberosum.

\section{Introduction}

The Brazilian production of potato, Solanum tuberosum, is one of the largest in the world (Amado et al., 2014, Brazinskiene et al., 2014) with an area of about 130,000 ha and a production of three million tons (FAO, 2013). This plant has a relatively shallow root system (Neumann et al., 2012) requiring large inputs of nutrients, especially nitrogen, to maintain productivity and tuber quality (Tein et al., 2014).

\footnotetext{
1 Horticulture Research Institute, 9 Gamaa Univeristy St., Orman, Giza. Egypt.

2 Universidade Federal de Viçosa - Dept. of Crop Science. Viçosa, MG, Brazil.

3 Universidade Federal de Viçosa - Dept. of Entomology. Viçosa, MG, Brasil, zanuncio@ufv.br.

* Corresponding author: maristela.watthier@ufv.br; rsantos@ufv.br.
}

Fecha de Recepción: 29 junio, 2016

Fecha de Aceptación: 21 febrero, 2017

DOI: $10.4067 / \mathrm{S} 0718-34292017005000016$ 
Leguminous plants as green manure represent an alternative to mineral fertilizers, as they fix, accumulate and provide large quantities of nitrogen to crops (Campiglia et al., 2010, Turgut et al., 2005). This may reduce or replace conventional chemical fertilizers in production systems, especially by releasing $\mathrm{N}$ in organic production systems (Ferreira et al., 2013). In addition, green manure can supply other nutrients and promote beneficial effects in physical, chemical and biological soil properties (Sharifi et al., 2014).

Growth patterns and dry matter distribution during the plant cycle are important for the management, yield and quality of potato tubers (Biemond and Vos, 1992). Nitrogen is vital for the accumulation and partitioning of dry matter between different parts of this plant (Kołodziejczyk, 2014).

The dry matter production of potato varies with climate, variety and management (Geremew et al., 2007), but has a linear increase with $\mathrm{N}$ supply up to certain levels (Zebarth et al., 2004), which improves its tuber quality (Roinila et al., 2003). Additionally, the total dry matter of potato accumulated by photosynthesis is utilized in different parts of the plant according to its development stage (Singh et al., 2008). However, each variety requires proper management of nitrogen fertilization (Brazinskiene et al., 2014), which makes it necessary to use correct doses of this nutrient for potato (Zebarth et al., 2009). The objective of this study was to evaluate the accumulation of dry matter, nitrogen and the productivity of potato with different quantities of sunn hemp, Crotalaria juncea $\mathrm{L}$ as nitrogen source.

\section{Material and Methods}

\section{Experimental site and preparation of the area}

The experiment was carried out from March to September 2012 in Viçosa, Minas Gerais State, Brazil in a region with cold, dry winter and wet, warm summer. This area is located at $20^{\circ} 45^{\prime} \mathrm{S}$, $42^{\circ} 51^{\prime} \mathrm{N}$ at an elevation of $693 \mathrm{~m}$. Two successive corn Zea mays L (Poaceae) crops were used to reduce the quantity of mineral $\mathrm{N}$ in the soil. The area was ploughed and tilled. Fertilization was complemented with other mineral nutrients than $\mathrm{N}$, according to a soil chemical analysis (Table 1).

\section{Sunn hemp production}

On 10 February 2012, sunn hemp seeds were manually sown, spaced $0.5 \mathrm{~m}$ between lines with a density of 40 seeds per linear meter, in the area next to the experimental field. The plants were harvested prior to full bloom (65 days after planting (DAP), air-dried, stored at a room temperature of $27^{\circ} \mathrm{C}$ and incorporated into the soil.

\section{Experimental design and management of plants}

The experiment had five treatments: 100 , 200 and $400 \mathrm{Kg} \mathrm{ha}^{-1}$ of sunn hemp as green manure (GM100, GM200, GM400), $250 \mathrm{Kg} \mathrm{ha}^{-1}$ of mineral $\mathrm{N}$ fertilizer ( $\mathrm{MN}$ ) and $\mathrm{N}$ zero (N0), in a randomized block design in subdivided plots, with four replications. The subplots represented

Table 1. Initial characteristics of the soil before the incorporation of sunn hemp, Crotalaria juncea (Fabaceae) and potato cultivation.

\begin{tabular}{llcl}
\hline \multicolumn{1}{c}{ Property } & \multicolumn{1}{c}{ Unit } & Value & \multicolumn{1}{c}{ Method } \\
\hline $\mathrm{OM}$ & $\mathrm{dag} \mathrm{kg}^{-1}$ & 3.0 & Walkely-Black = org C×1.724 \\
$\mathrm{pH}$ (in water1: 2.5) & & 5.3 & \\
$\mathrm{P}$ & $\mathrm{mg} \mathrm{dm}^{-3}$ & 37.7 & Mehlich-1 extractor \\
$\mathrm{K}$ & $\mathrm{mg} \mathrm{dm}^{-3}$ & 45.0 & Mehlich-1 extractor \\
$\mathrm{Ca}^{2+}$ & $\mathrm{cmol}_{\mathrm{c}} \mathrm{dm}^{-3}$ & 3.0 & KCL-1 $\mathrm{mol} \mathrm{L}^{-1}$ extractor \\
$\mathrm{Mg}^{2+}$ & $\mathrm{cmol}_{\mathrm{c}} \mathrm{dm}^{-3}$ & 0.5 & KCL-1 $\mathrm{mol} \mathrm{L}^{-1}$ extractor \\
$\mathrm{Al}^{3+}$ & $\mathrm{cmol}_{\mathrm{c}} \mathrm{dm}^{-3}$ & 0.0 & KCL-1 $\mathrm{mol} \mathrm{L}^{-1}$ extractor \\
Effective CTC & $\mathrm{cmol}_{\mathrm{c}} \mathrm{dm}^{-3}$ & 3.66 & \\
$\mathrm{CTC}$ in pH 7.0 & $\mathrm{cmol}_{\mathrm{c}} \mathrm{dm}^{-3}$ & 8.61 & \\
V & $\%$ & 43.0 & \\
Rem-P & $\mathrm{mg} \mathrm{L}^{-1}$ & 37.3 & \\
Texture & & Sandy clay & \\
\hline
\end{tabular}


the sampling times, $35,50,65$ and 80 days after planting (DAP). The experimental plot was 3.75 $\times 2.5 \mathrm{~m}$ with a corridor of $0.5 \mathrm{~m}$ between each to prevent contamination between treatments during the incorporation of the green manure. The dry matter of sunn hemp, corresponding to $\mathrm{N}$ doses, was incorporated a week before potato planting. The mineral nitrogen was supplied as ammonium sulfate; $70 \%$ was placed in the furrows before planting, and $30 \%$ as side dressing 22 days after the emergence of potato plants.

Tubers of potato cultivar Ágata (average weight $25 \mathrm{~g}$ and pre-germinated at a room temperature of $27^{\circ} \mathrm{C}$ under indirect sunlight) were planted when their shoots reached about $3 \mathrm{~cm}$ length. Irrigation, pest and disease control were carried out according to recommendations for this crop.

\section{Dry matter, harvest index, nitrogen recovery, apparent nitrogen recovery and productivity}

The accumulation of dry matter was quantified by the growth of the aerial and underground parts of potato, except roots, from the beginning of tuber formation to its senescence. Two plants per plot were uprooted at 35, 50, 65 and $80 \mathrm{DAP}$, and dried at $60^{\circ} \mathrm{C}$ to constant weight.

The harvest index (HI) was obtained in the last sampling (80 DAP), dividing the dry matter of the tubers $\left(\mathrm{Kg} \mathrm{ha}^{-1}\right)$ by the total potato plant dry matter $\left(\mathrm{Kg} \mathrm{ha}^{-1}\right)$ as follows: $\mathrm{HI}=\frac{\text { Tuber dry matter }\left(\mathrm{kg} \mathrm{ha}^{-1}\right)}{\text { Total dry matter }\left(\mathrm{kg} \mathrm{ha}^{-1}\right)}$

Nitrogen accumulation $\left(\mathrm{Kg} \mathrm{ha}^{-1}\right)$ was obtained by summing the amounts of foliage and tuber $\mathrm{N}$ to represent the total $\mathrm{N}$ accumulated per plant and then expressed on a per hectare basis. Apparent Nitrogen Recovery (ANR\%) was calculated following the equation (Lynch et al. (2008):

$$
\operatorname{ANR}(\%)=\frac{\mathrm{N} \text { uptake for treatment }-\mathrm{N} \text { uptake for ON treatment }}{\mathrm{N} \text { applied in the treatment }} \times 100
$$

The total and commercial productivity was obtained from 10 potatoes plants harvested in the central lines at 103 DAP. The tubers were harvested and classified (Moreira et al., 2000) in: C1-class 1 (diameter $>8.5 \mathrm{~cm})$, C2-class $2(8.5 \leq$ diameter $\geq 4.5 \mathrm{~cm}), \mathrm{C} 3$-class 3 ( $4.5 \leq$ diameter $\geq$ $3.3 \mathrm{~cm}$ ) and C4-class 4 (tubers with a diameter less than $3.3 \mathrm{~cm}$ and/or with commercial disorders such as greening, rotting or with insect or disease damage). The sum of classes 1, 2 and 3 represented the commercial productivity $(\mathrm{CP})$, and that of all classes the total productivity (TP) of potato:

$$
\begin{gathered}
\mathrm{TP}=\mathrm{C} 1+\mathrm{C} 2+\mathrm{C} 3+\mathrm{C} 4 \\
\mathrm{CP}=\mathrm{C} 1+\mathrm{C} 2+\mathrm{C} 3
\end{gathered}
$$

\section{Statistical Analysis}

Data were subjected to analysis of variance with the SAEG software version 9.1 (SAEG, 2007). The treatments were the plots, and the sampling dates the subplots. The dry matter accumulation data were submitted to quadratic regression analysis with the treatments established and time considered as a dependent factor. The results of the other variables were subjected to analysis of variance, and the means compared by the Tukey test $(\mathrm{p}<0.05)$.

\section{Results and discussion}

\section{Dry matter in shoots, tubers and total potato}

Dry matter accumulation in shoots of potato reached a maximum of $1,250.5 ; 1,137.53$ and $918.32 \mathrm{Kg} \mathrm{ha}^{-1}$ at 59.0, 57.5 and 63.5 DAP with 400, 200 and $100 \mathrm{Kg} \mathrm{ha}^{-1}$ of sunn hemp, respectively; $822.57 \mathrm{Kg} \mathrm{ha}^{-1}$ at $64.5 \mathrm{DAP}$ with mineral fertilizer and $683.12 \mathrm{Kg} \mathrm{ha}^{-1}$ for the NO at the end of the cycle, 71.6 DAP (Figure 1). These values were lower in all treatments after 65 DAP (Table 2).

The greater dry matter accumulation in the potato shoots with green manure is likely associated with greater availability of nitrogen in the soil, allowing its absorption by the plant and tuber growth (Biemond and Vos, 1992). Additionally, higher availability of nitrogen increases the expansion rate of leaves, total solar radiation intercepted and dry matter accumulation in the plant (Ospina et al., 2014). On the other hand, the lowest dry matter accumulation in the potato shoots with $\mathrm{N} 0$ and $\mathrm{MN}$ may be due to low availability of $\mathrm{N}$ for the tissues of this part of potato plants, causing premature defoliation under low doses of this nutrient (Goffart et al., 2008). The lowest dry mass in the shoots of potato after 65 DAP is due to early senescence of its leaves at the end of the cycle when photoassimilates are translocated to the tubers (Mustonen et al., 2010).

Dry matter accumulation in potato tubers at 35 and 50 DAP was greater in GM200 and GM400 

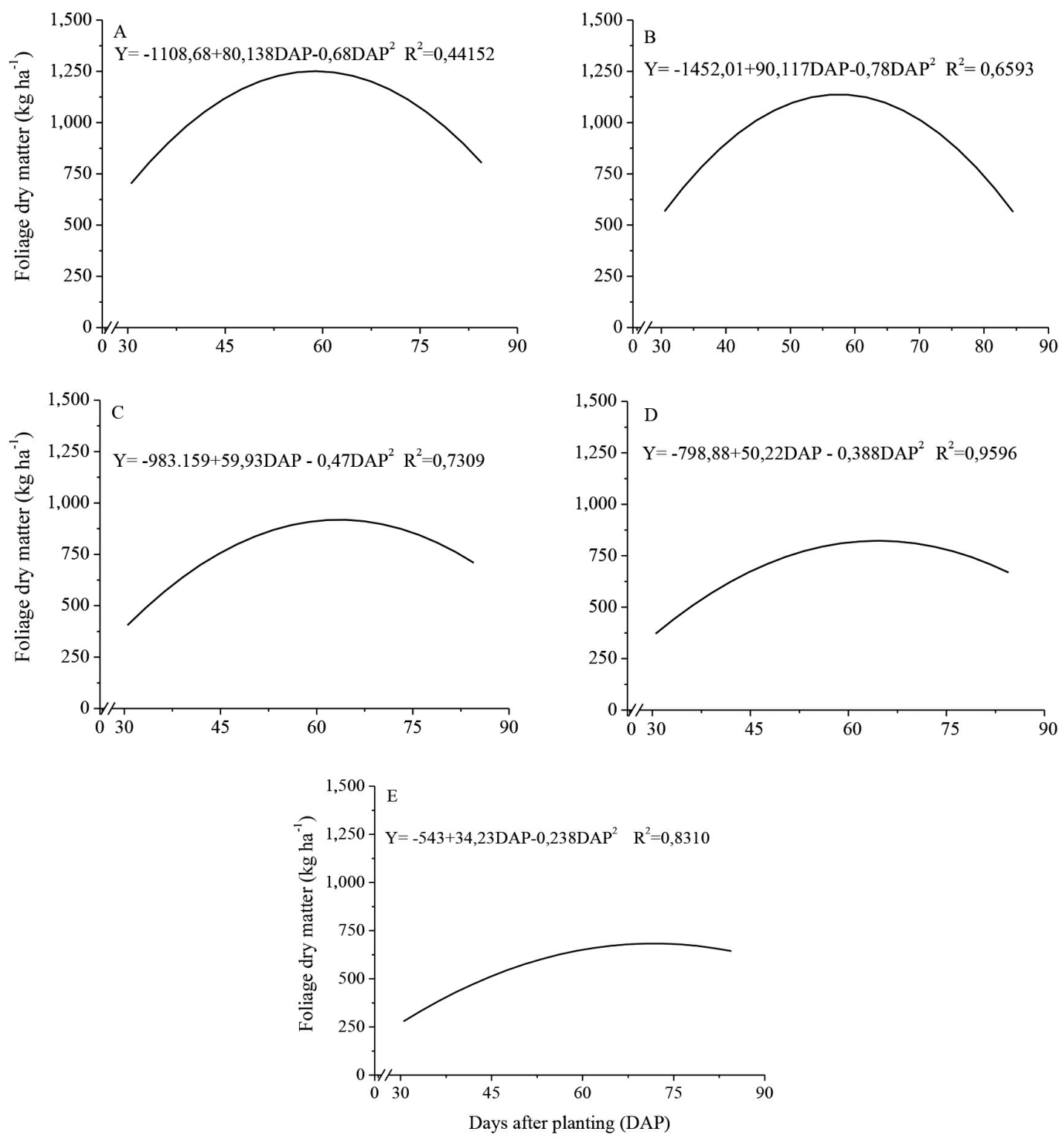

Figure 1. Dry matter accumulation in the above-ground parts of Solanum tuberosum (Solanaceae) $\left(\mathrm{Kg} \mathrm{ha}^{-1}\right)$ as a function of DAP with different fertilization treatments. Green manure $\left(400 \mathrm{Kg} \mathrm{ha}^{-1}\right)(\mathrm{A})$, green manure $\left(200 \mathrm{Kg} \mathrm{ha}^{-1}\right)(\mathrm{B})$, green manure $\left(100 \mathrm{Kg}\right.$ ha $\left.{ }^{-1}\right)$ (C), mineral nitrogen $\left(250 \mathrm{Kg} \mathrm{ha}^{-1}\right)(\mathrm{D})$, and zero nitrogen (E).

treatments than in GM100, MN and N0, and in the GM400 than in MN and N0 at 65 and 80 DAP, respectively (Table 2). Total dry matter accumulation was greater with green manure than with mineral fertilization or N0 (Table 2).

The greater dry matter accumulation in potato tubers with green manure is due to nitrogen and availability of other elements such as phosphorus, potassium, magnesium, boron, manganese and zinc in green manure, absorbed and allocated as dry matter in the potato tubers (Soratto et al., 2012; Rembialkowska et al., 2007). However, the lower dry matter accumulation in tubers of the plant with mineral fertilizer is due to the negative correlation with nitrogen (Roinilla et al., 2003); larger quantities of mineral nitrogen enhance the growth of the tuber, but with lower concentrations of dry matter and starch (Tein et al., 2014). Additionally, leaf growth 
Table 2. Dry matter accumulation in shoots, tubers and total per plant $\left(\mathrm{Kg} \mathrm{ha}^{-1}\right)$ potato under different treatments at 35 , 50,65 and 80 days after planting (DAP).

\begin{tabular}{lcccc}
\hline \multirow{2}{*}{ Treatments } & 35 DAP & 50 DAP & 65 DAP & 80 DAP \\
\cline { 2 - 5 } & \multicolumn{4}{c}{ Dry matter accumulation in potato shoots } \\
\hline AV400 & $793.75^{\mathrm{a}}$ & $1,403.13^{\mathrm{a}}$ & $1,018.75^{\mathrm{a}}$ & $1,015.63^{\mathrm{a}}$ \\
AV200 & $700.00^{\mathrm{b}}$ & $1,218.75^{\mathrm{b}}$ & $968.130^{\mathrm{a}}$ & $781.250^{\mathrm{ab}}$ \\
AV100 & $537.50^{\mathrm{c}}$ & $828.130^{\mathrm{c}}$ & $921.880^{\mathrm{a}}$ & $787.500^{\mathrm{ab}}$ \\
NM & $481.25^{\mathrm{d}}$ & $743.750^{\mathrm{d}}$ & $818.750^{\mathrm{ab}}$ & $731.250^{\mathrm{ab}}$ \\
N0 & $347.50^{\mathrm{e}}$ & $615.630^{\mathrm{e}}$ & $628.130^{\mathrm{b}}$ & $681.250^{\mathrm{b}}$ \\
LSD & 53.73 & 66.19 & 214.19 & 292.89 \\
\hline Treatments & \multicolumn{5}{c}{ Dry matter accumulation in potato tubers } \\
\hline AV400 & $368.97^{\mathrm{a}}$ & $2,232.65^{\mathrm{a}}$ & $4,028.11^{\mathrm{a}}$ & $5,646.99^{\mathrm{a}}$ \\
AV200 & $356.30^{\mathrm{a}}$ & $2,122.47^{\mathrm{a}}$ & $3,480.67^{\mathrm{ab}}$ & $4,901.10^{\mathrm{ab}}$ \\
AV100 & $224.02^{\mathrm{b}}$ & $1,837.86^{\mathrm{b}}$ & $2,833.15^{\mathrm{b}}$ & $5,307.98^{\mathrm{ab}}$ \\
NM & $173.18^{\mathrm{c}}$ & $1,400.56^{\mathrm{c}}$ & $2,919.19^{\mathrm{b}}$ & $4,404.54^{\mathrm{b}}$ \\
N0 & $116.99^{\mathrm{d}}$ & $1,130.55^{\mathrm{c}}$ & $1,973.67^{\mathrm{c}}$ & $3,220.75^{\mathrm{c}}$ \\
LSD & 36.21 & 282.58 & 708.29 & $1,071.54$ \\
\hline Treatments & \multicolumn{4}{c}{ Accumulation of total dry plant matter } \\
\hline AV400 & $1,162.72^{\mathrm{a}}$ & $3,635.78^{\mathrm{a}}$ & $5,046.86^{\mathrm{a}}$ & $6,662.61^{\mathrm{a}}$ \\
AV200 & $1,056.30^{\mathrm{b}}$ & $3,341.22^{\mathrm{a}}$ & $4,448.80^{\mathrm{ab}}$ & $5,682.35^{\mathrm{ab}}$ \\
AV100 & $710.680^{\mathrm{c}}$ & $2,665.98^{\mathrm{b}}$ & $3,755.03^{\mathrm{b}}$ & $6,095.47^{\mathrm{ab}}$ \\
NM & $705.270^{\mathrm{c}}$ & $2,144.31^{\mathrm{c}}$ & $3,737.94^{\mathrm{b}}$ & $5,135.79^{\mathrm{b}}$ \\
N0 & $464.490^{\mathrm{d}}$ & $1,746.18^{\mathrm{d}}$ & $2,601.80^{\mathrm{c}}$ & $3,902.00^{\mathrm{c}}$ \\
LSD & 67.18 & 310.6 & 814.45 & $1,022.53$ \\
\hline Nens & & & &
\end{tabular}

Means followed by the same letter in a column do not differ by the Tukey test ( $\mathrm{p}<0.05)$. AV: green manure. NM: $250 \mathrm{Kg} \mathrm{ha}^{-1}$ of mineral fertilizer. N0: zero nitrogen. 400200 and 100: Numerical values related to the dose of $\mathrm{N}\left(\mathrm{Kg} \mathrm{ha}^{-1}\right)$. LSD: Least significant difference.

is reduced and premature defoliation occurs with low nitrogen, which reduces the translocation of assimilates to the tubers, and consequently their dry matter (Goffart et al., 2008).

\section{Harvest index}

The harvest index $(\mathrm{HI})$ of potato was similar between treatments, with values of $0.846,0.862$, 0871, 0.857 and 0.825 for GM400, GM200, GM100, MN and NO, respectively. The similar HI between treatments is due to the ability of the potato to distribute photoassimilates formed in its aerial part to the tubers (Mazid et al., 2013). The harvest index was higher than those reported for potato, 0.70-0.85 with different nitrogen doses (Mazurczyk et al., 2009; Bélanger et al., 2001) or the 0.72 for this crop fertilized with compost and subterranean clover (Canali et al., 2010). The highest harvest index with the lowest green manure dose (GM100) is due to the higher translocation and absorption efficiency by tubers of this plant with lower amounts of $\mathrm{N}$ in the soil (Canali et al., 2010).
Greater availability of $\mathrm{N}$ reduces the translocation of carbon to leaves and tubers and increases the flow of this element to new leaves instead of driving it to the tubers. This leads to excessive growth of the aerial parts of potato, which reduces the HI (Oparka, 1987; Mazurczyk et al., 2009).

\section{Nitrogen accumulation and apparent nitrogen recovery}

$\mathrm{N}$ accumulation in potato was higher with the $400 \mathrm{Kg} \mathrm{ha}^{-1}$ sunn hemp dose and mineral fertilizer, reaching values of 92.3 and $81.27 \mathrm{Kg} \mathrm{ha}^{-1}$, respectively. Nevertheless, the apparent $\mathrm{N}$ recovery was inversely proportional to the sunn hemp dose (Table 3). Higher $\mathrm{N}$ accumulation in potato at higher sunn hemp doses is due to the rapid mineralization and $\mathrm{N}$ release of the green manure tissues (Diniz et al., 2014). On the other hand, decrease of ANR as the sunn hemp dose increased shows that the increase of $\mathrm{N}$ absorption and accumulation happens at a lower rate than the increase of $\mathrm{N}$ supply by the green manure. In addition, not all the $\mathrm{N}$ in green manure tissues is promptly mineralized (Matos et al., 2011) and a large part of the mineralized $\mathrm{N}$ is directed to soil organic matter (Bimüller et al., 2013).

\section{Total and commercial productivity of potato}

Commercial and total productivity of potato was higher with GM400 (41.62 ton ha ${ }^{-1}$ ) than in the other treatments. Commercial productivity of this crop increased by 9.9 and 4.9 ton ha ${ }^{-1}$ with 400 and $200 \mathrm{Kg} \mathrm{ha}^{-1}$ of green manure compared to the treatment with mineral fertilizer (Figure 2).

The highest commercial and total potato productivity with green manure is attributed to

Table 3. Harvest Index (HI), Nitrogen Accumulation

(NA) and Apparent N Recovery (ANR) in a potato crop at 80 days after planting.

\begin{tabular}{llcc}
\hline Treatments & HI & NA $\left(\mathrm{kg} \mathrm{ha}^{-1}\right)$ & ANR (\%) \\
\hline AV400 & $0.846^{\mathrm{ns}}$ & $92.31^{\mathrm{a}}$ & 13.28 \\
AV200 & 0.862 & $72.75^{\mathrm{b}}$ & 16.72 \\
AV100 & 0.871 & $70.87^{\mathrm{b}}$ & 31.30 \\
MN & 0.857 & $81.27^{\mathrm{ab}}$ & 16.68 \\
N0 & 0.825 & $39.59^{\mathrm{c}}$ & - \\
LSD & 0.117 & 13.11 & - \\
CV $(\%)$ & 2.84 & 8.15 & - \\
\hline
\end{tabular}



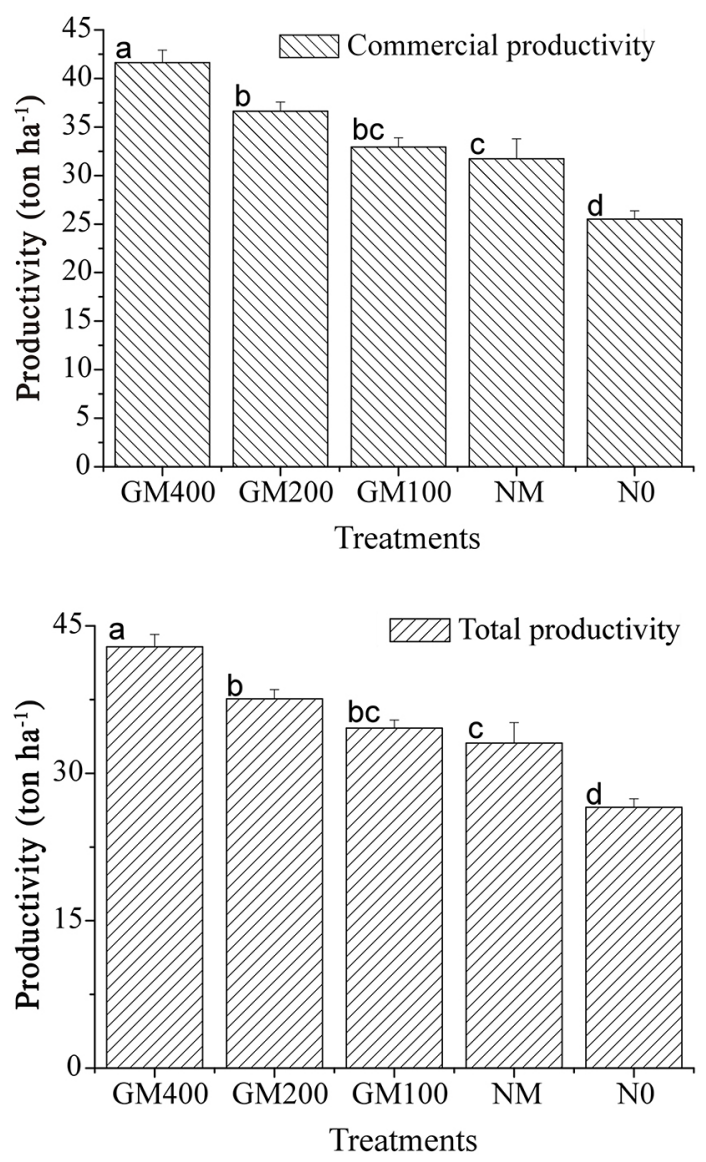

Figure 2. Total and commercial productivity of Solanum tuberosum (Solanaceae) with green manure (400 $\left.\mathrm{Kg} \mathrm{ha}^{-1}\right)(\mathrm{GM} 400)$, green manure $\left(200 \mathrm{Kg} \mathrm{ha}^{-1}\right)(\mathrm{GM} 200)$, green manure (100 Kg ha-1) (GM100), mineral nitrogen $\left(250 \mathrm{Kg} \mathrm{ha}^{-1}\right)(\mathrm{MN})$ and NO. Means followed by the same letter do not differ by Tukey test $(\mathrm{p}<0.05)$.

nitrogen supply; about 35\% higher production was reported after the incorporation of common vetch Vicia sativa L. and broad bean Vicia faba than with mineral fertilizer (Sincik et al., 2008).
There was increased growth and production of tomatoes under cultivation of hairy vetch Vicia villosa, demonstrating the efficiency of $\mathrm{N}$ supply by green manure (Campiglia et al., 2010, Tosti et al., 2012) and increased yields of sweet corn with field pea and common vetch (Turgut et al., 2005). Green manure improves the physical, chemical and biological properties of soil (Sharifi et al., 2014) including water retention, cation exchange capacity and microbial activity (Riutta et al., 2012; Dash et al., 2014). In addition, green manure reduces weed incidence (Campiglia et al., 2010) and soil pathogens by increasing beneficial microorganisms, as well as controlling disease-causing pathogens in potato (Davis et al., 2010, Larkin et al., 2010, Himmelstein et al., 2014). This contributes to a better growth condition of the crop, greater absorption of other soil nutrients and an increase in productivity (Aghili et al., 2014, Campiglia et al., 2009), and the sustainability of cropping systems (St Luce et al., 2015).

Green manure at $400 \mathrm{Kg} \mathrm{ha}^{-1}$ and $200 \mathrm{Kg} \mathrm{ha}^{-1}$ of C. juncea increases the accumulation of dry matter in potato shoots and tubers. The productivity of this crop was $24 \%$ greater with green manure than with mineral fertilization, indicating the potential of sunn hemp to provide nitrogen for the growth and development of potato.

\section{Acknowledgements}

To the "Conselho Nacional de Desenvolvimento Científico e Tecnológico (CNPq)". "Coordenação de Aperfeiçoamento de Pessoal de Nível Superior (CAPES)" and "Fundação de Amparo à Pesquisa do Estado de Minas Gerais (FAPEMIG)" for financial support. Global Edico Services rewrote the English of this manuscript.

\section{Literature Cited}

Aghili, F.; Gamper, H.A.; Eikenberg, J.; Khoshgoftarmanesh, A.H.; Afyuni, M.; Schulin, R.; Jansa, J.; Frossard, E. 2014. Green manure addition to soil increases grain zinc concentration in bread wheat. PLoS ONE, 9 (7): 1-13.

Amado, I.R.; Franco, D.; Sánchez, M.; Zapata, C.; Vázquez, J.A. 2014. Optimisation of antioxidant extraction from Solanum tuberosum potato peel waste by surface response methodology. Food Chemistry, 165: 290-299.

Bélanger, G.; Walsh, J.R.; Richards, J.E.; Milbum, P.H.; Ziadi, N. 2001. Tuber growth and biomass partitioning of two potato cultivars grown under different $\mathrm{n}$ fertilization rates with and without irrigation. American Journal of Potato Research, 78 (2): 109-117.

Brazinskiene, V.; Asakaviciute, R.; Miezeliene, A.; Alencikiene, G; Ivanauskas, L.; Jakstas, V.; Viskelis, P.; Razukas, A.

2014. Effect of farming systems on the yield, quality parameters and sensory properties of conventionally and organically grown potato (Solanum tuberosum L.) tubers. Food Chemistry, 145: 903-909.

Campiglia, E.; Caporali, F.; Radicetti, E.; Mancinelli, R. 2010. Hairy vetch (Vicia villosa Roth.) cover crop residue management for improving weed control and yield 
in no-tillage tomato (Lycopersicon esculentum Mill.) production. European Journal of Agronomy, 33 (2): 94-102.

Campiglia, E.; Mancinelli, R.; Radicetti, E.; Caporali, F.

2010. Effect of cover crops and mulches on weed control and nitrogen fertilization in tomato (Lycopersicon esculentum Mill.). Crop Protection, 29 (4): 354-363.

Campiglia, E.; Paolini, R.; Colla, G.; Mancinelli, R. 2009. The effects of cover cropping on yield and weed control of potato in a transitional system. Field Crops Research, 112 (1): 16-23.

Canali, S.; Ciaccia, C.; Antichi, D.; Bàrberi, P.; Montemurro, F.; Tittarelli, F.

2010. Interactions between green manure and amendment type and rate: Effects on organic potato and soil mineral $\mathrm{N}$ dynamic. Journal of Food, Agriculture and Environment, 8 (2): 537-543.

Davis, J.R.; Huisman, O.C.; Everson, D.O.; Nolte, P.; Sorensen, L.H.; Schneider, A.T.

2010. Ecological relationships of verticillium wilt suppression of potato by green manures. American Journal of Potato Research, 87 (4): 315-326.

Diniz, E.R.; Vargas, T.O.; Guedes, A.F.; Santos, R.H.S.; Peternelli, L.A.

2014. Decomposição e mineralização do nitrogênio proveniente do adubo verde Crotalaria juncea. Cientifica, 2014: 51-59.

Fernandes, A.M.; Soratto, R.P.; Silva, B.L.; de Souza-Schlick, G.D. 2010. Crescimento, acúmulo e distribuição de matéria seca em cultivares de batata na safra de inverno. Pesquisa Agropecuaria Brasileira, 45 (8): 826-835.

Ferreira, E.P.B.; Stone, L.F.; Didonet, A.D.

2013. Green Manure Species and Sowing Time Effects on the Agronomic Performance of Common Bean. Agronomy Journal, 105 (6): 1721.

Geremew, E.B.; Steyn, J.M.; Annandale, J.G.

2007. Evaluation of growth performance and dry matter partitioning of four processing potato (Solanum tuberosum) cultivars. New Zealand Journal of Crop and Horticultural Science, 35 (3): 385-393.

Goffart, J.P.; Olivier, M.; Frankinet, M.

2008. Potato crop nitrogen status assessment to improve $\mathrm{N}$ fertilization management and efficiency: Past-presentfuture. Potato Research, 51 (3-4): 355-383.

Himmelstein, J.; Maul, J.E.; Everts, K.L.

2014. Impact of cover crop green manures and Actinovate on Fusarium wilt of watermelon. Plant Diseae First (July): 965-972.

Kołodziejczyk, M.

2014. Effectiveness of nitrogen fertilization and application of microbial preparations in potato cultivation. Turkish Journal of Agriculture and Forestry, 38 (3): 299-310.

Larkin, R.P.; Griffin, T.S.; Honeycutt, C.W.

2010. Rotation and cover crop effects on soilborne potato diseases, tuber yield, and soil microbial communities. Plant Disease, 94 (12): 1491-1502.

Matos, E.D.S.; Mendonça, E.D.S.; Cardoso, I.M.; Lima, P.C. D.E.; Freese, D.

2011. Decomposition and nutrient release of leguminous plants in coffee agrooforestry systems. Revista Brasileira de Ciencia do Solo do Solo, 35 (6): 141-149.
Mazid, M.S.; Rafii, M.Y.; Hanafi, M.M.; Rahim, H.A.; Latif, M.A. 2013. Genetic variation, heritability, divergence and biomass accumulation of rice genotypes resistant to bacterial blight revealed by quantitative traits and ISSR markers. Physiologia Plantarum, 149 (3): 432-447.

Mazurczyk, W.; Wierzbicka, A.; Trawczyński, C. 2009. Harvest index of potato crop grown under different nitrogen and water supply. Acta Sci. Pol, 8 (4): 15-21.

Mustonen, L.; Wallius, E.; Hurme, T.

2010. Nitrogen fertilization and yield formation of potato during a short growing period. Agricultural and Food Science, 19 (2): 173-183.

Neumann, A.; Torstensson, G.; Aronsson, H.

2012. Nitrogen and phosphorus leaching losses from potatoes with different harvest times and following crops. Field Crops Research, 133: 130-138.

Ospina, C.A.; Lammerts van Bueren, E.T.; Allefs, J.J.H.M.; Engel, B.; van der Putten, P.E.L.; van der Linden, C.G.; Struik, P.C.

2014. Diversity of crop development traits and nitrogen use efficiency among potato cultivars grown under contrasting nitrogen regimes. Euphytica, 199 (1-2): 13-29.

Riutta, T.; Slade, E.M.; Bebber, D.P.; Taylor, M.E.; Malhi, Y.;

Riordan, P.; Macdonald, D.W.; Morecroft, M.D.

2012. Experimental evidence for the interacting effects of forest edge, moisture and soil macrofauna on leaf litter decomposition. Soil Biology and Biochemistry, 49: 124-131.

Sharifi, M.; Lynch, D.H.; Hammermeister, A.; Burton, D.L.; Messiga, A.J.

2014. Effect of green manure and supplemental fertility amendments on selected soil quality parameters in an organic potato rotation in Eastern Canada. Nutrient Cycling in Agroecosystems, 100 (2): 135-146.

Sincik, M.; Turan, Z.M.; Göksoy, A.T.

2008. Responses of potato (Solanum tuberosum L.) to green manure cover crops and nitrogen fertilization rates. American Journal of Potato Research, 85 (2): 150-158.

Singh, R.K.; Singh, J.P.; Lal, S.S.

2008. Dry matter partitioning relative to development in high yielding indian potato cultivars under short day tropical conditions. Potato Journal, 35: 161-166.

Soratto, R.P.; Crusciol, C.A.C.; da Costa, C.H.M.; Neto, J.F.; Castro, G.S.A.

2012. Produção, decomposição e ciclagem de nutrientes em resíduos de crotalária e milheto, cultivados solteiros e consorciados. Pesquisa Agropecuaria Brasileira, 47 (10): 1462-1470.

Soratto, R.P.; Fernandes, A.M.; de Souza-Schlick, G.D.

2011. Extração e exportação de nutrientes em cultivares de batata: II - Micronutrientes. Revista Brasileira de Ciencia do Solo, 35 (6): 2057-2071.

St Luce, M.; Grant, C.A.; Zebarth, B.J.; Ziadi, N.; O’Donovan, J.T.; Blackshaw, R.E.; Harker, K.N.; Johnson, E.N.; Gan, Y.; Lafond, G.P.; May, W.E.; Khakbazan, M.; Smith, E.G.

2015. Legumes can reduce economic optimum nitrogen rates and increase yields in a wheat-canola cropping sequence in western Canada. Field Crops Research, 179: 12-25. 
Tein, B.; Kauer, K.; Eremeev, V.; Luik, A.; Selge, A.; Loit, E. 2014. Farming systems affect potato (Solanum tuberosum L.) tuber and soil quality. Field Crops Research, 156: 1-11.

Tosti, G.; Benincasa, P.; Farneselli, M.; Pace, R.; Tei, F.; Guiducci, M.; Thorup-Kristensen, K.

2012. Green manuring effect of pure and mixed barley - hairy vetch winter cover crops on maize and processing tomato N nutrition. European Journal of Agronomy, 43: 136-146. Turgut, I.; Bilgili, U.; Duman, A.; Acikgoz, E.; Turgut, I.; Bilgili, U.; Duman, A.; Acikgoz, E.
2005. Effect of green manuring on the yield of sweet corn. Agron. Sustain. Dev 25.

Zebarth, B.J.; Drury, C.F.; Tremblay, N.; Cambouris, A.N. 2009. Opportunities for improved fertilizer nitrogen management in production of arable crops in eastern Canada: A review. Canadian Journal of Soil Science, 89 (2): 113-132.

Zebarth, B.J.; Tai, G.; Tarn, R.; de Jong, H.; Milburn, P.H. 2004. Nitrogen use efficiency characteristics of commercial potato cultivars. Canadian Journal of Plant Science, 84 (2): 589-598. 